\title{
GROWTH AND NODULATION OF PEANUT GROWN IN SANDY SOIL AMENDED WITH OLIVE WASTES
}

(Received: 30-8-2008)

\author{
By \\ A. A. Al-Kahal, El-S. A. Hassan and W. D. Saleh ${ }^{*}$ \\ Soils, Water and Environment Research Institute, Agricultural Research Center, Giza \\ * Department of Agriculture Microbiology, Faculty of Agriculture, Cairo University, Giza \\ (Correspondent auther).
}

\begin{abstract}
The effect of untreated olive mill wastewater (OMW) and crude olive cake as organic fertilizers, alone or in mixture with poultry manure, on nodulation and growth of peanut plants was investigated in a pot experiment under sandy-soil conditions. The application of low concentrations of either OMW or olive cake significantly increased the number and dry weight of nodules, shoots dry weight and N-content after 50 days of planting. The addition of poultry manure alone or in combination with olive wastes decreased all the abovementioned parameters. Plants fertilized with OMW combined with poultry manure scored the minimum number and dry weight of nodules. Incorporation of olive wastes into soil, with or without poultry manure, decreased nodulation parameters after 70 days of planting. Addition of OMW decreased shoots dry weight and N-content. Generally, soil amended with olive cake exhibited less toxicity compared to soil fertilized with OMW. Amendment with olive wastes and/or poultry manure increased the total flavonoids and soluble phenols of peanut plants compared with those inoculated with Rhizobium spp. only. The increase of total soluble phenols was insignificant.

It is concluded that the application of OMW or crude olive waste with or without poultry manure caused inhibitory effect on nodulation and growth of peanut plants in sandy soil.
\end{abstract}

Key words: nodulation, olive cake, olive mill wastewater, rhizobium.

\section{INTRODUCTION}

Olive oil extraction produces vast amounts of residues, in the form of liquid and solid wastes. Olive mill waste water (OMW) and crude olive cake are produced as waste-products in olive oil factories. Olive mill waste water, commonly called alpechin, is the main waste produced by three-phase extraction of olive oil. The treatment and disposal of this liquid are the main problems of olive-oil industry. The phytotoxic properties of OMW are mainly attributed to the relatively high concentration of polyphenols, which are also known to possess antibacterial properties which resist biological degradation (Perez et al., 1992 and Aktas et al., 2001). Crude olive cake also contains phenolic compounds which are toxic to many plant species and resistant to degradation (Estaun et al., 1985 and Gonzalez et al., 1990).

The advantage of using olive wastes as organic fertilizers is their high contents of plant nutrients such as $\mathrm{N}, \mathrm{P}, \mathrm{K}$ and organic matter, (Paredes et al., 1999). The disadvantage mainly is the high contents of phenols which are toxic to soil and plants (Tomati and Galli, 1992; Sierra et al., 2001; Casa et al., 2003 and Cereti et al., 2004).

Nodulation, nitrogen fixation and growth in legume-Rhizobium symbiosis are affected by the application of untreated olive wastes as an organic fertilizer. Al-kahal, et al. (2001) found that increasing the levels of olive-oil wastewater or olive-cake suppressed nodulation and growth of faba bean plants cultivated in a clay loam soil after 80 days from planting in the presence of Bradyrhizobium spp.. Mekki et al. (2006) observed that untreated olive mill wastewater inhibited germination and growth of tomato, chickpea, bean, wheat and barley. Hence, a conditioning treatment of this waste is compulsory to safely produce organic fertilizers. Some authors have pointed out that the toxicity of olive wastes introduced into soil is reduced when mixed with different nitrogen sources such as urea, polymers, anhydrous ammonia or poultry manure. The 
mixture of olive wastes and such $\mathrm{N}$ sources is characterized by a wider $\mathrm{C} / \mathrm{N}$ ratio, which stimulates microbial degradation of the phytotoxic compounds of olive wastes (Rodriguez-Kabana et al., 1995).

The aim of the present investigation was to examine the effect of either olive mill wastewater or olive cake alone or in combination with poultry manure on nodulation and growth of peanut plants in sandy soils.

\section{MATERIALS AND METHODS}

A pot experiment was executed in the greenhouse of the Agricultural Research Center at Giza - Egypt. The soil used was sandy $(\mathrm{pH}, 7.1$; EC, $0.47 \mathrm{dSm}^{-1}$; organic carbon, $0.25 \%$; total nitrogen, $0.01 \%$ ). The soil was distributed into earthenware pots at the rate of $10 \mathrm{~kg} /$ pot. The used poultry manure has $60 \%$ organic matter, 2.50 $\%$ total $\mathrm{N}, 0.21 \%$ total $\mathrm{P}$ and $0.92 \%$ total $\mathrm{K}$. Olive mill wastewater and crude olive cake were obtained from Olive Oil Extraction Unit, ARC Giza. The major properties of these products are presented in Table (1).

Air dried crude olive cake and the poultry

Table (1): Some physiochemical properties of OMW and crude olive cake.

\begin{tabular}{|c|c|c|}
\hline Character & OMW & $\begin{array}{l}\text { Crude olive } \\
\text { cake }\end{array}$ \\
\hline Moisture content \% & 80 & 7 \\
\hline pH & 4.9 & 4.7 \\
\hline$E C \mathrm{dSm}^{-1}$ & 18.16 & 3.45 \\
\hline Organic matter \% & 40.00 & 55.00 \\
\hline Total Nitrogen \% & 1.46 & 0.96 \\
\hline Protein content $\%$ & 6.20 & 8.20 \\
\hline Organic carbon\% & 23.23 & 32.47 \\
\hline C/N ratio & 16 & 34 \\
\hline Fat $\%$ & 0.50 & 6.80 \\
\hline Ash \% & 3.20 & 3.52 \\
\hline Total P \% & 0.20 & 0.16 \\
\hline Total K \% & 5.20 & 1.14 \\
\hline Total phenols \% & 1.00 & 1.20 \\
\hline
\end{tabular}

manure were ground and incorporated into soil at a rate of the $20 \mathrm{~g} / 10 \mathrm{~kg}$ soil. All pots received super-phosphate at a rate of $2 \mathrm{~g} / \mathrm{pot}$ (200kg/feddan), and potassium sulfate $\left(48 \% \mathrm{~K}_{2} \mathrm{O}\right)$ at a rate of $0.5 \mathrm{~g} /$ pot, as $24 \mathrm{~kg} \mathrm{~K}{ }_{2} \mathrm{O} / \mathrm{fed}$. Pots were initially kept for 2 weeks to facilitate decomposition of the introduced organic materials. This was followed by allocating the six experimental treatments with six replicates as follows: inoculated plants (peanut seeds inoculated with Rhizobium spp. as a control; plants inoculated with Rhizobium spp. and amended with OMW at a rate of $20 \mathrm{ml} / 10 \mathrm{~kg}$ soil; plants inoculated with Rhizobium spp. and amended with poultry manure at a rate of 20 g/10kg soil; plants inoculated with Rhizobium spp. and received olive cake and poultry manure; plants inoculated with Rhizobium spp. and treated with olive cake along with poultry manure. Rhizobium spp. inoculum was prepared by growing the bacteria, in shake flasks, on yeast extract mannitol medium, YEM (Vincent, 1970) at $30^{\circ} \mathrm{C}$ for 3 days until early $\log$ phase $\left(5 \times 10^{9}\right.$ $\mathrm{cfu} / \mathrm{ml})$, then transferred to sterile fine peatmoss neutralized with $5 \% \quad \mathrm{CaCO}_{3}$. Seeds were inoculated at a rate of $400 \mathrm{~g}$ inoculum $/ 40 \mathrm{~kg}$ seeds/ feddan using Arabic gum solution (16\%) at a rate of $400 \mathrm{ml} /$ feddan.

OMW was added at seed sowing. Eight seeds of peanut cv. Giza 6 were sown in each pot. Pots were arranged in a complete randomized block design. Pots were watered when needed. Plants were thinned to 3 plants/ pot after one week. Nitrogen fertilizer was added two weeks after sowing at a rate of $1 \mathrm{~g} /$ pot as ammonium sulfate $(20.5 \%)$. Plant samples were collected after 50 and 70 days of planting to determine nodules number and dry weight besides shoots dry weight. $\mathrm{N}$-content of dried peanut shoots was determined by micro-kejldahel method (Page et al., 1983). Data were subjected to analysis of variance using the statistical analysis system computer package M-STAT (Snedecor and Cochran, 1989).

\section{RESULTS AND DISCUSSION}

\subsection{Nodulation and growth of 50-day old peanut}

Data shown in Table (2) present the effect of OMW and crude olive cake alone or in combination with poultry manure on the nodulation status of peanut plants after 50 days of planting. The application of either OMW or olive cake as an organic amendment, at low concentrations, caused a significant increase in the number and dry weight of nodules compared with the plants inoculated with Rhizobium spp. only. Addition of poultry manure, as such, led to insignificant decrease in the number and dry weight of nodules. Plants supplied with poultry manure together with OMW scored the lowest number and dry weight of nodules.

In spite of untreated olive wastes (either OMW or olive cake) being characterized by the presence of phytotoxic substances, mainly phenolic compounds, which may affect symbiotic nitrogen fixation by Bradyrhizobium (Tomati and 
Table (2): Nodulation and growth of peanut plants as affected by the application of olive wastes and poultry manure after 50 days of planting.

\begin{tabular}{|l|c|c|c|c|}
\hline Treatment & $\begin{array}{c}\text { No. of } \\
\text { nodules/ } \\
\text { plant }\end{array}$ & $\begin{array}{c}\text { Dry weight of } \\
\text { nodules (mg/ } \\
\text { plant) }\end{array}$ & $\begin{array}{c}\text { Dry weight of } \\
\text { shoots (g/plant) }\end{array}$ & $\begin{array}{c}\text { N- content } \\
\text { of shoots } \\
\text { (mg/plant) }\end{array}$ \\
\hline Control (Rhizobium) & 62 & $\mathbf{0 . 3 3}$ & 13.48 & 3.08 \\
\hline OMW & $\mathbf{8 5}$ & $\mathbf{0 . 4 1}$ & 15.34 & 3.78 \\
\hline Olive cake & 102 & $\mathbf{0 . 4 2}$ & 15.58 & 3.57 \\
\hline Poultry manure (P.M.) & 54 & $\mathbf{0 . 2 4}$ & 13.87 & 3.22 \\
\hline OMW.+ P.M. & $\mathbf{2 4}$ & $\mathbf{0 . 1 5}$ & 13.73 & 2.52 \\
\hline Olive-Cake.+ P.M. & $\mathbf{5 3}$ & $\mathbf{0 . 2 4}$ & 14.83 & $\mathbf{2 . 1 7}$ \\
\hline L.S.D. at 5\% & 12 & $\mathbf{0 . 6}$ & $\mathbf{2 . 1 6}$ & $\mathbf{0 . 8 0}$ \\
\hline
\end{tabular}

Galli, 1992), some investigators reported that some strains of Bradyrhizobium spp. are able to utilize a wide range of aromatic compounds such as phenolics as carbon or nitrogen sources. Gajendrian and Mahadevan (1990) reported that Bradyrhizobium spp., isolated from Labab purpureus, survived for nine months in soil containing the phenolic derivative catechol. Also, Chen et al. (1984) mentioned that Rhizobium leguminosarum was able to grow on a number of organic compounds and utilized 4hydroxybenzoate in the presence of glucose and succinate. Abbas (2000) studied the effect of olive cake, at very low concentrations, on Leucaena plants grown in sandy soils. He found that olive cake increased the number of nodules over that due to inoculation with Bradyrhizobium spp. only. Al-Kahal (2001) found that faba bean cultivated in clay soil amended with olive oil wastewater at a rate of $1 \%$ had higher number and dry weight of nodules after 50 days of planting compared with plants inoculated with Rhizobium leguminosarum only. On the other hand, peanut plants fertilized with poultry manure, as a source of organic fertilizer, in the presence of rhizobial inoculation exhibited a reduction in the number and dry weight of nodules. This might be attributed to the high $\mathrm{N}$ content of poultry manure; the majority of $\mathrm{N}$ is in the form of uric acid that can be rapidly converted to ammonium nitrogen if temperature, moisture and $\mathrm{pH}$ are suitable for microbial activity (Sims and Woelf, 1994).

Heavy $\mathrm{N}$ dressing inhibited nitrogenase activity and this, in turn, led to a decrease in symbiotic nitrogen fixation. Addition of OMW, even at low concentration, along with poultry manure recorded the lowest numbers and dry weights of nodules.
Concerning the effect of olive wastes, alone or in combination with poultry manure, on the dry weight and $\mathrm{N}$-content of peanut shoots at 50-day growth period, there was an increase in dry weight of shoots in all treatments compared with the plants inoculated with Rhizobium spp. only, but this increase was insignificant. Addition of olive wastes or poultry manure increased $\mathrm{N}$-content compared to inoculation with Rhizobium spp. only. On the other hand, N-content of the plants treated with a combination of OMW and poultry manure was decreased. This decrease was also observed in the plants amended with olive cake and poultry manure. These results indicate that the addition of either OMW or olive cake, with or without poultry manure, somewhat had a stimulative effect on peanut shoot biomass. This is probably due to the high organic matter content of olive wastes, along with the notable levels of nitrogen in both OMW and olive cake (Paredes et al., 1999).

\subsection{Nodulation and growth after 70 days of planting}

Results of the influence of olive wastes application alone or in combination with poultry manure on nodulation status and growth of peanut plants after 70 days of planting are given in Table (3). There was an inhibitory effect due to application of olive wastes or poultry manure in all treatments compared to the control. The highest number and dry weight of nodules were recorded in the plants inoculated with Rhizobium spp. only, followed by those inoculated with Rhizobium spp. simultaneously amended with olive cake. The minimum values of the abovementioned parameters were recorded in the plants fertilized with either OMW plus poultry manure or those amended with olive cake and poultry manure. 
Table (3): Nodulation and growth of peanut plants as affected by the application of olive wastes and poultry manure after 70 days of planting.

\begin{tabular}{|l|c|c|c|c|}
\hline Treatment & $\begin{array}{c}\text { No. of } \\
\text { nodules/ } \\
\text { plant }\end{array}$ & $\begin{array}{c}\text { Dry weight of } \\
\text { nodules } \\
\text { (mg/ plant) }\end{array}$ & $\begin{array}{c}\text { Dry weight } \\
\text { of shoots } \\
\text { (g/plant) }\end{array}$ & $\begin{array}{c}\text { N- content of } \\
\text { shoots } \\
\text { (mg/plant) }\end{array}$ \\
\hline Control (Rhizobium) & 200 & 0.53 & 22.49 & 4.72 \\
\hline OMW & 175 & 0.37 & 19.47 & 4.60 \\
\hline Olive cake & 178 & 0.49 & 22.24 & 3.85 \\
\hline Poultry manure (P M) & 123 & 0.37 & 21.37 & 2.94 \\
\hline OMW+ P M. & 109 & $\mathbf{0 . 3 8}$ & 21.87 & 3.36 \\
\hline Olive-Cake.+ P M & 141 & $\mathbf{0 . 4 5}$ & 23.54 & 3.99 \\
\hline L.S.D. at 5\% & 10 & $\mathbf{0 . 1 0}$ & $\mathbf{8 . 1 9}$ & 1.30 \\
\hline
\end{tabular}

Suppressive effect of olive wastes on the nodulation status in peanut plants cultivated in sandy soil was obvious after 70 days from planting, this is probably due to increasing the concentration of phenolic compounds in the soil after degradation of olive wastes, while the application of poultry manure led to significant reduction in the number and dry weight of nodules compared to the plants inoculated with Rhizobium spp. only. Addition of poultry manure along with olive wastes did not diminish the toxicity of olive wastes in terms of the number and dry weight of nodules compared with the plants amended with olive wastes only.

Table (3) shows that peanut, treated with Rhizobium spp. and amended olive cake, scored the highest shoots dry weight followed by plants inoculated with Rhizobium spp. and amended with a mixture of olive cake and poultry manure, however, this increase was insignificant. Plants inoculated with Rhizobium spp. only gave the highest N-content followed by those inoculated with Rhizobium spp. and fertilized with OMW. In this respect, Ciafardini and Zullo (1998) studied the effect of OMW on the symbiotic activity of Rhizobium meliloti and Rhizobium hedysarii in soil and in sand, and found that the soil protects the symbionts from the toxic action of OMW better than sand trials.

\subsection{Influence of olive wastes and/or poultry} manure on total flavonoids and total soluble phenols

Table (4) reveals that there was an increase in total flavonoids and soluble phenols in the peanut plants' dry-weight in all treatments with either olive wastes or poultry manure compared with those inoculated with Rhizobium spp. only. The increase of total flavonoids was significant in the first period while the increase was insignificant in the concentrations of soluble phenols in both periods, This indicates that the addition of olive wastes at a low concentration and/or poultry manure as organic amendments is considered a source of phenolic compounds in the soil and in plants as well.

Addition of poultry manure scored the highest value of total flavonoids in peanut plants after 50 days, while addition of $\mathrm{O} \mathrm{M} \mathrm{W}$ combined with poultry manure scored the highest values of flavonoids and total soluble phenols after 70 days. As mentioned before, peanut plants fertilized with poultry manure reduced the number and dry weight of nodules after 50 and 70 days of planting. This was attributed not only to the excess of $\mathrm{N}$ provided by poultry manure that inhibit nitrogenase enzyme activity, but also to the high content of phenolic compounds in poultry manure that may affect the nodulation processes.

Therefore, such negative effects of olive wastes and or poultry manure even at low concentrations are associated with the presence of phytotoxic compounds especially high content of phenolics, as reported by (Paredes et al., 1999).

From these results, it could be concluded that the application of olive wastes, either in the form of OMW or crude olive cake, at low concentrations in sandy soil had a suppressive effect on the nodulation and growth of peanut plants in the absence or presence of poultry manure. Such negative effects are associated with its low $\mathrm{pH}$, and mainly to the presence of phytotoxic compounds, especially phenols. Negative effects have also been recorded in soil properties, including the immobilization of available nitrogen (Perez and Gallardo-Lara, 
Table (4): Effect of olive wastes and/or poultry manure on total flavonoids and total soluble phenols in the dry weight of peanut plants.

\begin{tabular}{|l|c|c|c|c|}
\hline \multirow{2}{*}{ Treatment } & \multicolumn{2}{|c|}{ Flavonoids\% } & \multicolumn{2}{c|}{ Soluble phenols\% } \\
\cline { 2 - 5 } & $\begin{array}{c}\text { 50-days old } \\
\text { plants }\end{array}$ & $\begin{array}{c}70 \text {-days old } \\
\text { plants }\end{array}$ & $\begin{array}{c}\text { 50-days old } \\
\text { plants }\end{array}$ & $\begin{array}{c}\text { 70-days old } \\
\text { plants }\end{array}$ \\
\hline Control & 3.661 & 3.189 & 2.311 & 1.768 \\
\hline O M W & 4.000 & 3.833 & 2.574 & 2.614 \\
\hline Olive cake & 4.267 & 4.120 & 2.903 & 2.685 \\
\hline Poultry manure & 5.057 & 4.503 & 3.406 & 2.660 \\
\hline O M W + P M & 4.420 & 4.637 & 2.742 & 2.865 \\
\hline Olive cake+ P M & 4.905 & 3.570 & 3.472 & 2.043 \\
\hline L.S.D. at 5\% & 1.295 & 1.561 & 1.226 & 1.473 \\
\hline
\end{tabular}

1987), the displacement of the exchange complex calcium by potassium in an anfisol, increased salinity (Lopez et al., 1996) and decreased plantavailable magnesium, perhaps because of the antagonistic effect of potassium (Perez et al., 1986).

These results are in line with those observed by many authors about the phytotoxic effect of OMW on plants when used directly as an organic fertilizer and have therefore opposed its direct application (Jelmini et al., 1976; Paredes et al., 1999). Therefore, before OMW or crude olive cake can be used properly and safely, toxicity must be eliminated or reduced. Different methods have been proposed for treatment of OMW or crude olive cake based on evaporation ponds, thermal concentration and different physicochemical and biological treatments (Paredes et al., 2005). However, most methods are expensive and unable to completely solve the problem because of the need to dispose sludge or other by-products deriving from the process. Recently, composting of olive wastes, especially OMW, is found to be the most acceptable treatment to reduce its toxicity (Cegarra et al., 1996; Paredes et al., 1999; Paredes et al.,1999 and 2005 and Walker and Bernal 2008).

In Egypt, extensive studies are needed on olive wastes composting process and the effect of its application on the yield and quality of different crops.

\section{REFERENCES}

Abbas M.T. (2000). Use of Agrotechnologies Based on Biological N-Fixation for the Benefit of Agriculture and Environment of
Sinai. PhD. Thesis, Fac. Agric., Cairo Univ., Egypt, 115 pp.

Aktas E.S., Imre S. and Eesoy L. (2001). Characterization and lime treatment of olive mill wastewater. Water Res., 35: 2336-2340.

Al-Kahal A.A., Mekhemer G.A.A. and Abo ELSoud A.A. (2001). Response of faba bean plants to organic fertilization with olive wastes. Annals Agric. Sci., Ain Shams Univ., Cairo, 46: 565-578.

Casa A.D., Annibale A., Pieruccetti F., Stazi S.R., Giovannozzi Sermanni G. and Lo Cascio B. (2003). Reduction of the phenolic cmponents in olive mill wastewater by an enzymatic treatment and its impact on durum wheat (Triticum durum Desf) germinability. Chemosphere, 50: 959- 966.

Cegarra J., Paredes C., Roig A., Bernal M.P. and Garcia D. (1996). Use of olive mill wastewater compost for crop production. International Biodeterioration \& Biodegradation, 38: 193-203.

Cereti C.F., Rossini F., Federici F., Quaratino D., Vassilev N. and Fenice M. (2004). Reuse of microbially treated olive mill wastewater as fertilizer for wheat (Triticum durum Desf). Bioresource Technol., 91: 135-140.

Chen Y.P., Glenn A.R. and Dilworth M.J. (1984). Uptake and oxidation of aromatic substances by Bradyrhizobium leguminosarum MNF 3841 and Bradyrhizobium melotii TAL. FEMS Microbiol. Lett., 21: 201-205. 
Ciafardini G. and Zullo B.A. (1998). Inhibitory effect of oil mill waste water on Rhizobium meliloti and Rhizobium hedysarii in the soil. Advances in Food Sciences, 20(3- 4): 89- 93.

Estaun, V., Calvet C. and Grasses J.M. (1985). Chemical determination of fatty acids, organic acids, and phenols during olive marc composting process. Acta Horticulture, 172: 263-270.

Gajendiran N. and Mahadevan A. (1990). Growth of Bradyrhizobium sp. in the presence of catechol. Plant and Soil, 125: 207-211.

Gonzalez M.D., Moreno, E., Quevedo-Sarmiento J. and Cormenzana R.A. (1990). Studies on olive oil mills (alpechin) inhibitory activity of phenolic and fatty acids. Chemosphere, 20: 423-432.

Jelmini M., Sanna M. and Pelosi N. (1976). Indagine sulle acque di rifiuto degli stabilimenti di produzione olearia in provincial di Roma: possibilita di depurazione. Ind. Aliment. Italy, 15(11): 123-131.

Lopez R., Martinez-Bordiu A., Dupuy de Lome, E., Cabrera F. and Sanchez M.C. (1996). Soil properties after application of olive oil wastewater. Fresenius Envir. Bull., 5, 4954.

Mekki A., Dohouib A., Aloubi F. and Sayadi S. (2006). Olive wastewater as an ecological fertilizer. Agron. Sustain. Dev., 26: 61-67.

Page A.L., Miller R.H. and Kenney D.R. (1983). Methods of Soil Analysis, Part 2: Chemical and Microbiological Properties. Second Edition., Am. Soc. Agron., Madison, Wisconsin USA . pp 610-616.

Paredes C., Cegarra J., Bernal M.P. and Roig A. (2005). Influence of olive mill wastewater in compositing and impact of the compost on a Swiss chard crop and soil properties. Environment International, 31: 305-312.

Paredes C., Cegarra J., Roig A., SanchezMonedero M.A. and Bernal M.P. (1999). Characterization of olive mill wastewater (alpechin) and its sludge for agricultural purposes. Bioresource Technol., 67: 111115.
Perez J.D. and Gallardo-Lara F. (1987). Effects of the application of wastewater from olive processing on soil nitrogen transformation. Commun. Soil Sci. Plant Anal., 18: 10311039.

Perez J., de la Rubia T. and Moreno J. (1992). Phenolic content and antibacterial activity of olive oil waste waters. Environ. Toxicol. Chem., 11: 489-495.

Perez J.D., Esteban E. and Gallardo-Lara F. (1986). Direct and delayed influence of vegetation water on magnesium uptake by crops. Proc. International Symposium on Olive by-products Valorization, Sevilla, Spain, Instituto Nacional de Investigaciones Agrarias, $580 \mathrm{pp}$.

Rodriguez-Kabana R., Estaun V., Pinochet J. and Marfa O. (1995). Mixtures of olive pomace with different nitrogen sources for the control of Meloidogyne spp. on tomato. Supplement to the Journal of Nematology, 27(4S): 575-584.

Sierra J., Marti E., Montserrat G.C., Ruanas R. and Garau M.A. (2001). Characterization and evaluation of a soil affected by olive mill wastewater disposal. Sci Total Environ., 279: 207-214.

Sims J.J. and Woelf D.C. (1994). Poultry waste management uses. Adv. Agron., 52: 1-83.

Snedecor G.W. and Cochran W.G. (1989). Statistical Methods. Eighth Ed., Iowa State Univ. Press, Ames, Iowa, USA, ISBN-10: 0813815614, ISBN-13: 9780813815619,503 pp.

Tomati U. and Galli E. (1992). The fertilizing value of waste water from the olive processing industry. In:" Humus, its Structure and Role in Agriculture and Environment", (Ed. Kubat. J.), ElSevien Science, Amsterdam, p. 117-126.

Vincent J.M. (1970) A Manual for the Practical Study of the Root-Nodule Bacteria . IBP Handbook. No.15, Blackwell Scientific Publishers, Oxford.

Walker D.J. and Bernal M.P. (2008). The effect of olive mill waste compost and poultry manure on the availability and plant uptake of nutrients in a highly saline soil. Bioresource Technol., 99:396-403. 


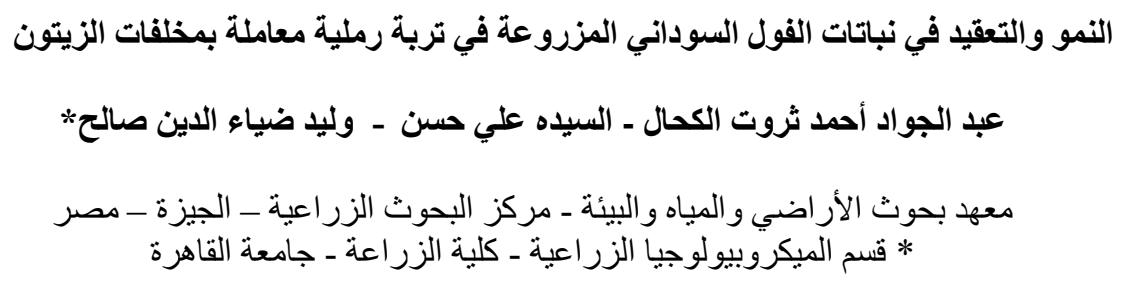

تمت در اسة تأثثر إضافة العصير المتخلف بعد استخلاص زيت الزيتون وكذللك كسب الزيتون كأسمدة عضوية سواء كإضـافة منفردة

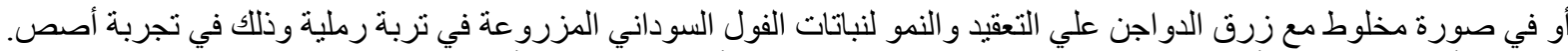

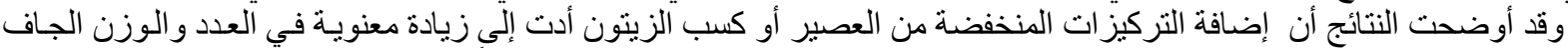

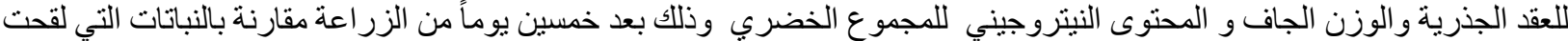

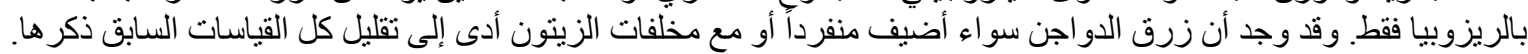

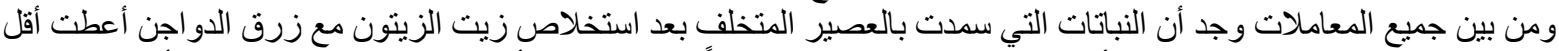

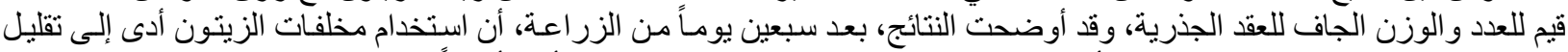

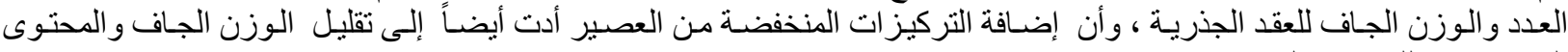
النيتروجيني للمجموع الخضود الخدري.

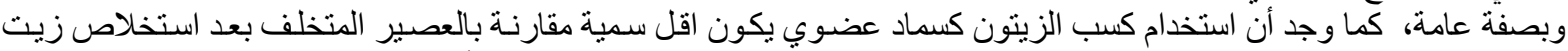

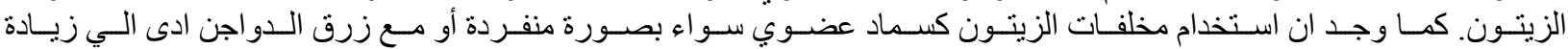

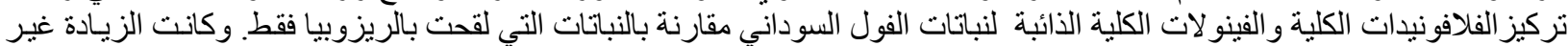

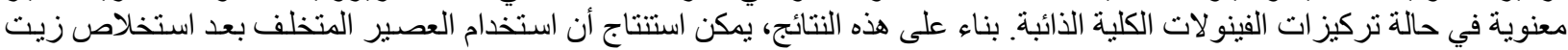

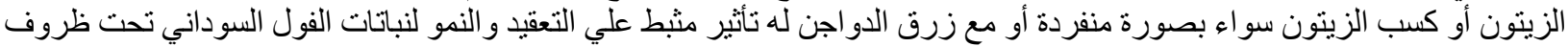
التربة الرملية.

المجلة العلمية لكلية الزراعة - جامعة القاهرة المجلد (59) العدد الرابع ( أكتوبر 2008): 306-312. 